\title{
JUURNAL.RU
}

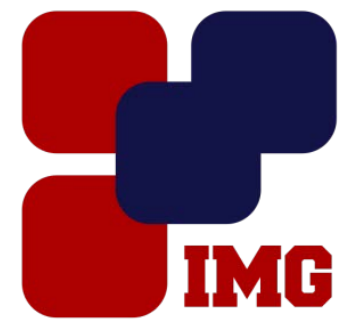
IYANOY Management GROUP

Авдеева Т.Г., Петриков Р.И. Красноярский государственный педагогический университет им.В.П.Астафьева Красноярск, Россия

doi: 10.18411/lj-25-12-2016-2-11

idsp 000001:lj-25-12-2016-2-11

\section{Образ мира как психологическая реальность}

\begin{abstract}
Аннотация
В статье раскрываются содержательные стороны образа мира в контексте психологических систем. Представлены теоретические подходы в психологической науке к данному феномену

Ключевые слова: образ, образ мира, психологические подходы, феномен

\section{Abstract}

The article reveals the substance of the image of the world in the context of psychological systems. Theoretical approaches in psychology to this phenomenon

Keywords: Image, world image, psychological approaches, the phenomenon
\end{abstract}

Определенный всем опытом жизнедеятельности субъекта, образ мира представляет собой тот «фон, на котором разворачивается вся психическая деятельность человека» [5, с.14]. Объективные условия для изучения образа мира открываются при сопоставлении качественно различных картин реальности [5], выбранного нами в качестве основной стратегии достижения цели магистерской диссертации. Определим ключевое понятие работы и представим традицию его изучения в психологической науке.

Категория «образ мира» была введена в понятийный аппарат психологии А.Н. Леонтьевым для обозначения совокупной системы значений, в которых мир репрезентируется в сознании субъекта, в рамках решения задачи «изучения психического как изучения «построения в сознании индивида многомерного образа мира, образа реальности» [3, с.254]. Признание того, что «в любом психическом акте человек воспроизводит мир в образе» [1], ведет к тому, что потребность изучения внутреннего мира человека, его субъективного опыта, который и составляет главный интерес психологической науки, должна найти предмет своего удовлетворения именно в изучении образа мира.

Сегодня «образ мира», как понятийная категория, имеет «огромный 
описательный потенциал для всей феноменологии познавательной деятельности человека и для всех направлений отечественной психологии» [6, с.11], хотя первоначально отвечала решению проблемы обобщения многочисленных эмпирических данных, накопленных в исследовании восприятия. В современных эмпирических работах «образ мира» понимается неоднозначно и получает многообразные определения, такие как: «система жизненных смыслов человека» (Горская, 2005); «индивидуальный мир человека» (Кондратова, 2009); «целостная система представлений «Я-Мир», включающая в себя подсистемы представлений «Мир» и «Я в мире» (Правник, 2007). Важно заметить, что в основе определений - попытка обозначить «образом мира» сложное субъективное переживание человеком окружающей действительности, внутренний мир личности, целостное пристрастное отношение к миру. Далее попытаемся проследить наполняемость и трансформированность содержание феномена «образ мира» в различных направления[2].

Одним из направлений исследования образа мира является теория личностных конструктов Дж. Келли. Цель теории - объяснить способы интерпретации и прогнозирования людьми своего жизненного опыта с точки зрения сходстваи различий. В аналитической теории К.Г. Юнга рассматривается вопрос об изменчивости образа мира как критерии его «хорошего» функционирования. Динамичность образа мира проявляется в том, что он может все время меняться, подобно изменчивости мнения человека о самом себе. Любая новая информация, новое знание человека о мире или о самом себе трансформирует его образ мира. «Образ мира» - это относительно стойкая, в большей или меньшей степени осознанная, пережитая как неповторимая система представлений о себе система, на основе которой человек строит свое отношение к другими людям и к себе [4]. Термин «образ мира» впервые предложен в 1975 году А.Н. Леонтьевым. В своих работах он использует понятие образа мира, говоря об особенностях процесса восприятия. Автор отмечает: «Конечно, в результате работы органов чувств возникает картина мира» [3, с. 142]. Согласно его представлениям, образ мира, созданный на основе некой действительности и ей принадлежащей, является амодальным. Таким образом, А.Н. Леонтьев обозначил такие особенности образа мира, как его амодальность, интегративность и обобщенность. Образ мира постоянно дополняется и изменяется новой поступающей информацией, посредством чувственных образов, вследствие чего образ мира динамичен.

Тогда, анализируя образ мира в его функциональном аспекте, мы можем выделить еще одно определение образа мира, предложенное С.Д. Смирновым [7]. Автор понимает образ мира как многоуровневую систему познавательных гипотез, основными функциями которой являются: непрерывная генерация познавательных гипотез, обеспечение «независимости» результата конкретного познавательного акта от непосредственно данной наличной ситуации, «образ есть момент движения деятельности» и образ мира выступает как опосредствующее звено в процессе экстериоризации и интериоризации 
деятельности. Образ мира человека является универсальной формой организации его значений, определяющей возможности познания и управления поведением.Однако многими исследователями предлагается более широкое понимание образа мира; его представленность на всех уровнях психической организации человека. Так, В.В. Петухов [5] выделяет в образе мира базовые, «ядерные» структуры, отражающие глубинные связи человека и мира, не зависящие от рефлексии, и «поверхностные», связанные с осознанным, целенаправленным познанием мира. Представление о мире определяется как фундаментальное условие психической жизни субъекта.В.В. Петухов в своей статье «Образ мира и психологическое изучение мышления» описывает образ мира как план внутренней деятельности субъекта, выполняющий побудительную и ориентировочную функции по отношению к системе реализуемых субъектом деятельностей. Автор вводит свое понятие представление мира, психологическое содержание которого раскрывается в трех утверждениях: во-первых, представление мира должно быть; во-вторых, представление мира есть; в-третьих, представление мира может существовать как предмет науки, то есть доступно объективному исследованию.

Интересна точка зрения Е.Ю. Артемьевой [1], которая определяет образ мира, как «интегратор» следов взаимодействия человека с объективной действительностью, выстраивая трехуровневую системную модель образа мира Первый уровень - «перцептивный мир», который характеризуется системностью значений и модальной перцептивной, чувственной предметности. Второй уровень - «картина мира» - отношения, а не чувственные образы, которые сохраняют свою модальную специфичность. Третий уровень - «образ мира» слой амодальных структур, которые образуются при обработке предыдущего уровня. Такие ученые, как С.Л. Рубинштейн, Б.Г. Ананьев, К.А. АбульхановаСлавская, рассматривают образ мира в контексте жизненного пути человека, через систему познания бытия в мире. Формирование образа мира происходит в процессе познания человеком окружающего его мира, осмысления значимых событий в своей жизни. Мир для человека предстает в конкретике реальности бытия и становящегося собственного «Я» человека [2].

В контексте обсуждения проблемы образа мира значимо понимание того, «образ мира» понимается, прежде всего, как отображение реального мира, в котором живет и действует человек, одновременно являясь частью этого мира. Образ мира - «не склад инструментов, приемов и программ», а живое начало, которое постоянно апробируется в деятельности, чтобы получит подтверждение своей адекватности миру.Раскрытие особенностей содержательного наполнения образа мира дает возможность лучше понять внутренний мир человека во взаимосвязи с реалиями бытия. Для проведения исследований особенностей образа мира как психологической реальности в контексте бытия человека в мире важно учитывать обсужденные выше подходы к данной проблеме. 


\section{Литература}

1. Артемьева Е.Ю. Основы психологии субъективной семантики / Под. ред. И.Б. Ханиной. - М.: Наука; Смысл, 1999. - 350 с.

2. Буровихина И.А. Возрастные особенности семантики образа мира // Вестник университета (Государственный университет управления). Социология, психология, педагогика и управление персоналом. - 2011. - № 14 - C. 16 - 18.

3. Леонтьев А.Н. Деятельность. Сознание. Личность / под ред. Д.А.Леонтьева. М.: Смысл; Академия, 2004. - 346 с.

4. Леонтьев А.Н. Лекции по общей психологии: Учеб. Пособие для вузов по спец. «Психология» / Под ред. Д.А. Леонтьева, Е.Е. Соколовой. -М.: Смысл, 2000. - $509 \mathrm{c}$.

5. Петухов В.В. Образ мира и психологическое изучение мышления // Вестн. Моск. ун-та. Сер. 14. Психология. 1984. № 21. С. 13-21.

6. Серкин В.П. Пять определений понятия и схема функционирования образа мира // Вестник МГУ. Серия 14. Психология, 2006 . - №1 - С.11 - 19.

7. Смирнов С.Д. Мир образов и образ мира // Вестник Московского университета. Серия 14: Психология. - 1981. - № 2. - С. 15-29. 